\title{
Risk assessment (chemical and radiological) due to intake of uranium through the ingestion of drinking water around two proposed uranium mining areas, Jharkhand, India
}

\author{
S. GIRI ${ }^{1, *}$, V.N. JHA ${ }^{2}$
}

(Manuscript received 1 February 2012, accepted 22 March 2012)

ABSTRACT Uranium is known for both chemical and radiological toxicity. East Singhbhum is known for uranium mining, and radionuclides can be expected in its groundwater. Groundwater was collected around two proposed sites of Bagjata and Banduhurang and analysed for $U$ (nat). The study reveals that the $U$ (nat) varied from $<0.5-11.2$ and $<0.5-27.5 \mu \mathrm{g} . \mathrm{L}^{-1}$ for the Bagjata and Banduhurang mining areas, respectively. The excess lifetime cancer risk due to the consumption of uranium in water was calculated to be in the range of $8.81 \times 10^{-6}$ to $4.34 \times 10^{-5}$ and $3.36 \times 10^{-6}$ to $9.55 \times 10^{-5}$ for the two study areas, which are within the acceptable cancer risk value of $1 \times 10^{-4}$. However, the risk at a few locations is very close to the threshold value. The chemical risk evaluated by the hazard quotient was found to be within $0.05-0.23$ and $0.02-0.6$ for the two study areas and did not exceed the limit of 1 . Thus, the concentration of $U$ (nat) in the groundwater presently does not pose any serious threat to local people but must be monitored periodically and adequate actions must be taken in the few areas with elevated levels of uranium in the groundwater.

Keywords: groundwater / India / uranium / risk assessment / hazard quotient / cancer risk

\section{Introduction}

Radionuclides can come into contact with water in several ways. They may be deposited from the air or may be released to the water from the ground through erosion, seepage, or human activities such as mining. Some radionuclides that reach either groundwater or surface water move with the water. Others deposit on the surrounding soil or rocks. Ingestion of radionuclides through drinking water and food intake accounts for a substantial part of the average radiation doses to various organs of the body and also represents one of the important pathways for long-term health considerations (UNSCEAR, 2000). Radioactive materials occur

1 Geo-Environment Division (EMG), Central Institute of Mining and Fuel Research, Dhanbad-826015, India.

Environmental Assessment Division, Bhabha Atomic Research Centre, Mumbai-400085, India

* Corresponding author: Dr. Soma Giri, e-mail: soma0307@gmail.com. 
naturally everywhere in the environment (e.g., uranium, thorium and potassium40). Some sources (e.g., uranium) can be concentrated during extraction by mining and other industrial activities (WHO, 2004).

It is important to investigate the natural radiological situation of the sites and the environment before the commencement of uranium mining to be able to assess the possible radiological impact of these activities in the future. As part of a baseline study, the concentration of radionuclides was determined in the groundwater around two proposed uranium mines in Bagjata and Banduhurang (Giri et al., 2011). In the present study, the chemical and radiological risk due to intake of uranium through the ingestion of drinking water was investigated.

\section{Materials and methods}

Natural uranium $\{U($ nat $)\}$ was evaluated by a fluorometric method (Kolthoff and Elving, 1962). The details of the study area, sampling and analysis are provided elsewhere (Giri et al., 2011).

\subsection{Risk from the intake of uranium through ingestion}

Uranium is a radionuclide which is known for both its chemical toxicity and radiological toxicity. It has been established that high concentrations of uranium greater than $15 \mu \mathrm{g} . \mathrm{L}^{-1}$ in domestic water may present harmful biological effects in humans (WHO, 2008). The main health threat related to uranium use is chemical toxicity (Keith et al., 1999). Like many other heavy metals, uranium is toxic to humans and animals, with the kidney being the target organ (Leggett, 1989). The toxic effects of uranium compounds have been extensively studied in the kidney (Guglielmotti et al., 1989; Kurttio et al., 2002) and bones of laboratory animals (Larivière et al., 2007). The chemical toxicity effects on the human kidney by chronic ingestion of uranium through drinking water in the range of 0.004 to $9 \mu \mathrm{g} . \mathrm{L}^{-1}$ per body weight per day may produce interference with kidney functions (Zamora et al., 1998). In a more recent study on humans by Kurttio et al. (2005), nephrotoxic effects of uranium in drinking water were found even for low concentrations - without a clear threshold. Most results from uranium studies in drinking water suggest that the safe concentration of uranium in drinking water may be within the range of proposed guideline values of 2-30 $\mu \mathrm{g} . \mathrm{L}^{-1}$ (Kurttio et al., 2002; WHO, 2008). Because uranium is a predominantly alpha-emitting radionuclide, there is concern about the potential DNA damage if the emitted alpha particles reach the cell nuclei of the body; for instance, through water ingestion. Attempts by cells to repair this damage, if it occurs, may result in repair errors, producing gene mutations or chromosomal aberrations. These effects, when 
sufficiently severe, may be manifested as cancer and possibly as developmental malformations in children and developing foetuses (Amakom and Jibiri, 2010). In this view, the assessment of radiological and chemical toxicity is essential. For the radiological toxicity, the excess lifetime cancer risk is estimated, while for the chemical toxicity the hazard quotient is calculated. International regulatory agencies such as the WHO and ICRP do not provide the values for slope factors and reference doses for radionuclides. Moreover, the most widely used values for SFo and RfD are given by US-EPA. So, the US-EPA values were used for the calculations.

\subsection{Excess lifetime cancer risk (absolute)}

Risk factors for different tissues were based upon the estimated likelihood of inducing fatal malignant disease, nonstochastic changes, or substantial hereditary disorders expressed in live-born descendents. The risk coefficients may be used to estimate the probability of radiogenic cancer mortality or morbidity per unit intake for a given radionuclide for internal exposure or per unit dose for external exposure. Federal guidance report No. 13 provides risk coefficents for specific radionuclides (US-EPA, 1999). The slope factors or risk coefficients are estimated using state-of-the-art methods and models for estimating the risks to health from internal or external exposure. These methods and models take into account a comprehensive compilation, and the age- and gender-specific aspects of radiation risk. The risk coefficient for exposure to a given radionuclide through a given environmental medium is expressed as the probability of radiogenic cancer mortality or morbidity per unit activity inhaled or ingested, for internal exposure, or per unit time-integrated activity concentration in air or soil, for external exposure. The risk coefficients are applicable to either chronic or acute exposure to a radionuclide. For purposes of computing the factors, it was assumed that the concentration of the radionuclide in the environmental medium remains constant and that all persons in the population are exposed to that environmental medium throughout their lifetimes.

A morbidity risk coefficient or slope factor is a comparable estimate of the average total risk of experiencing a radiogenic cancer, whether or not the cancer is fatal. For each of the internal exposure modes, the risk coefficient for a radionuclide includes the contribution to dose from production of decay chain members in the body after intake of the parent radionuclide, regardless of the halflives of the decay chain members.

The excess lifetime carcinogenic risk can be estimated by multiplying the average daily dose $(A D D)$ with the slope factor $(S F)$ and the duration of life (75.2 years). In the case of uranium the slope factor is $6.4 \times 10^{-11}$ (US-EPA, 1989). 
In the 1970s, the US Food and Drug Agency (FDA) was the first agency to address the issue, adopting a risk level of 1-in-1-million $\left(10^{-6}\right)$ as the incremental cancer risk for carcinogenic residues in foods that was considered to be "essentially zero" (Kelly, 1991). The origin of this "essentially zero" risk level was purely arbitrary. Since then, the $10^{-6}$ risk level has become commonplace in the regulation and management of environmental contaminants, with the strongest endorsement coming from the US-EPA, which employs $10^{-6}$ as its primary risk benchmark for "acceptable" exposure to carcinogens within the general population. Although a 1in-1-million $\left(10^{-6}\right)$ cancer risk is the most frequently used risk level for the management of risks posed by environmental (including soil) contamination, many agencies and provinces, including the US-EPA, identify a range of increased cancer incidence risks; generally, from 1-in-10 000 (or $1 \times 10^{-4}$ ) to 1 -in-1 000000 (or $\left.1 \times 10^{-6}\right)$ is considered an acceptable risk range depending on the situation and circumstances of exposure (Graham, 1993; Kelly, 1991; Lohner, 1997; Travis et al., 1987; US-EPA, 1991). Thus, in general, the US-EPA considers excess cancer risks that are below about 1 chance in $1000000\left(1 \times 10^{-6}\right)$ to be so small as to be negligible, and risks above $1 \times 10^{-4}$ to be sufficiently large that some sort of remediation is desirable. The upper boundary of the risk range is not a discrete line at $1 \times 10^{-4}$, although the EPA generally uses $1 \times 10^{-4}$ in making risk management decisions. A specific risk estimate around $10^{-4}$ may be considered acceptable if justified based on site-specific conditions. Some studies have even reported $10^{-3}$ as the acceptable level for the radiological risk (Ye-shin et al., 2004).

The basic equation for calculating excess individual lifetime cancer risk is:

$$
\text { Risk }=A D D \times S F_{\mathrm{o}} \times 27448 \text { days }(75.2 \text { years })
$$

where:

- Risk = a unitless probability of an individual developing cancer over a lifetime;

- $A D D=$ average daily dose $(\mathrm{pCi})$;

- $S F_{\mathrm{o}}=$ slope factor, expressed in (risk/pCi).

The risk is related to doses but since the US-EPA - integrated risk information system (IRIS) database has provided slope factors $\left(S F_{\mathrm{o}}\right)$ in unit activity/risk which is specific for each radionuclide, the same procedure is adopted for the assessment (US-EPA, 1993). The slope factors are given in the units of risk/pCi so the activities are converted from $\mathrm{Bq}$ to $\mathrm{pCi}$. The conversion factor used is $1 \mathrm{~Bq}=27 \mathrm{pCi}$.

\subsection{Hazard quotient}

The EPA uses the "Reference Dose" approach to evaluate chronic (long-term) exposure to systemic toxicants. The reference dose $(R f D)$ is defined as "an estimate 
(with uncertainty spanning perhaps an order of magnitude) of a daily exposure to the human population (including sensitive subgroups) that is likely to be without appreciable risk of deleterious effects during a lifetime" and is expressed as a $\mathrm{mg} / \mathrm{kg} /$ day dose. The $R f D$ is usually based on the most sensitive known effect; that is, the effect that occurs at the lowest dose. Although some RfDs are based on actual human data, they are most often calculated from results obtained in chronic or subchronic animal studies. The basic approach for deriving an $R f D$ or $R f C$ involves determining a "No-Observed-Adverse-Effect Level (NOAEL)" or "Lowest-Observed-Adverse-Effect Level (LOAEL)" from an appropriate toxicological or epidemiological study and then applying various uncertainty factors and modifying factors to arrive at the RfD. RfDs can be used to evaluate risks from chronic exposure to systemic toxicants. In the case of uranium also, the values were developed by analysing the biological effects of test animals given relatively large amounts of uranium, then adjusting and normalizing the results to a mg/kg-day basis for humans (US-EPA, 1994a).

The EPA defines an expression of risk called a "hazard quotient" by which the risk of the chemical toxicant may be characterized. This is the ratio of the Average Daily Dose ( $A D D$; milligrams per kilogram body weight per day) of a chemical to a reference dose (RfD, milligrams per kilogram per day). Hazard quotient values below unity imply that adverse effects are very unlikely to occur. The $R f D_{\mathrm{o}}$ of uranium (0.003) was considered from US-EPA (1993).

$$
H Q=\frac{A D D}{R f D}
$$

If $H Q>1.00$, then the $A D D$ of a particular metal exceeds the $R f D$, indicating that there is a potential risk associated with that metal.

For the calculation of the excess lifetime cancer risk and hazard quotient, the average water consumption of $1.48 \mathrm{~m}^{3} \cdot \mathrm{y}^{-1}$ (4 L/day) by an Indian adult (Dang et al., 1994) was used. The average daily dose $(A D D)$ was calculated by dividing the intake by the body weight of an average Indian man, i.e. $52 \mathrm{~kg}$ (Jain et al., 1995; Dang et al., 1996). The values are different from a Caucasian reference man (body weight $=60 \mathrm{~kg}$ and average water consumption $=2 \mathrm{~L} /$ day). As the study is from India, the values from the Indian reference were taken for better approximation of the risk.

\section{Results and discussion}

The overall concentration range of uranium, considering all the seasons, varied from $<0.5 \mu \mathrm{gL}^{-1}$ to $11.2 \mu \mathrm{g} . \mathrm{L}^{-1}$ in the Bagjata area, whereas for the Banduhurang area it ranged from $<0.5 \mu \mathrm{g} . \mathrm{L}^{-1}$ to $27.5 \mu \mathrm{g} . \mathrm{L}^{-1}$ (Tab. I). $0.5 \mu \mathrm{g} . \mathrm{L}^{-1}$ was the method 
TABLE I

Concentration of $U(n a t)$ in groundwater of Bagjata and Banduhurang mining areas.

\begin{tabular}{|c|c|c|c|c|c|c|c|c|c|c|}
\hline \multirow{2}{*}{$\begin{array}{l}\text { S. } \\
\text { No. }\end{array}$} & \multirow{2}{*}{$\begin{array}{l}\text { Location } \\
\text { (Bagjata) }\end{array}$} & \multicolumn{4}{|c|}{$\mathrm{U}\left(\right.$ nat) in $\mu \mathrm{g} . \mathrm{L}^{-1}$} & \multirow{2}{*}{$\begin{array}{c}\text { Location } \\
\text { (Banduhurang) }\end{array}$} & \multicolumn{4}{|c|}{$\mathrm{U}\left(\right.$ nat) in $\mu \mathrm{g} . \mathrm{L}^{-1}$} \\
\hline & & $\begin{array}{c}\text { Jun. } \\
06\end{array}$ & $\begin{array}{c}\text { Sept. } \\
06\end{array}$ & $\begin{array}{c}\text { Jan. } \\
\text { 07. }\end{array}$ & $\begin{array}{c}\text { May } \\
07\end{array}$ & & $\begin{array}{c}\text { Jun. } \\
\text { 06 }\end{array}$ & $\begin{array}{c}\text { Sept. } \\
06\end{array}$ & $\begin{array}{l}\text { Jan. } \\
\text { 07 }\end{array}$ & $\begin{array}{c}\text { May } \\
07\end{array}$ \\
\hline 1 & Bagjata & 7.8 & $<0.5$ & 2.1 & 2.7 & Keoradungri & 1.2 & $<0.5$ & 0.6 & $<0.5$ \\
\hline 2 & Bhaduya & 10.6 & 1.2 & 5.2 & 10.1 & Babudungri & 7.7 & $<0.5$ & $<0.5$ & 1.2 \\
\hline 3 & Phuljhari & 2.2 & $<0.5$ & 1.3 & 5 & Chota Talsa & 0.7 & 3 & 1.5 & 2.1 \\
\hline 4 & Manajhari & 0.9 & $<0.5$ & 3.8 & 2.3 & Kudada & 0.6 & $<0.5$ & $<0.5$ & 0.8 \\
\hline 5 & Balidungri & 3.5 & $<0.5$ & 0.7 & 1.3 & Matku & 0.9 & $<0.5$ & $<0.5$ & 0.6 \\
\hline 6 & Bakra & 3.7 & 2.3 & 1.4 & 2.1 & Dhatkidih & 2.4 & $<0.5$ & 1.6 & 1.9 \\
\hline 7 & Katsakra & 4.8 & 3.4 & 4.1 & 4.9 & Sundernagar & 1 & $<0.5$ & 1.3 & 0.7 \\
\hline 8 & Gohala & 11.2 & 9 & 8.5 & 7.4 & Talsa & 3.1 & $<0.5$ & 2.8 & 4.3 \\
\hline 9 & Latia & 5.1 & 4.1 & $<0.5$ & 3.5 & Turamdih & 0.7 & $<0.5$ & 0.9 & 0.6 \\
\hline 10 & Mosabani & 3.4 & 1.5 & 3.1 & 2.5 & Nandup & 21.4 & $<0.5$ & 27.5 & 20.3 \\
\hline \multicolumn{2}{|c|}{ Geomean } & 4.26 & 2.84 & 2.61 & 3.49 & & 1.82 & - & 2.0 & 1.64 \\
\hline
\end{tabular}

detection limit. Comparison of the concentration range of $\mathrm{U}($ nat) in groundwater with the US-EPA standards (US-EPA, 1994b, 2003) and WHO standards (WHO, 2011) shows that the radionuclide lies within the prescribed limits $\left(30 \mu \mathrm{g} . \mathrm{L}^{-1}\right)$ for both the study areas. The statistical analysis of the data indicated geometric mean concentrations of $\mathrm{U}(\mathrm{nat})$ in the Bagjata and Banduhurang areas were found to be $3.31 \mu \mathrm{g} . \mathrm{L}^{-1}$ and $1.83 \mu \mathrm{g} . \mathrm{L}^{-1}$, respectively, with geometric standard deviations of $2.0 \mu \mathrm{g} . \mathrm{L}^{-1}$.

\subsection{Excess lifetime cancer risk due to intake of uranium through drinking water}

The data was used for calculating the excess lifetime cancer risk assessment by the US-EPA method (US-EPA, 1993). The excess lifetime cancer risk due to the consumption of water was calculated to be in the range of $\left(8.81 \times 10^{-6}\right)-\left(4.34 \times 10^{-5}\right)$ for the Bagjata area, with the highest risk in Gohala village (uranium concentration of $11.2 \mu \mathrm{g} . \mathrm{L}^{-1}$ in June 2006), and in the range of $\left(3.36 \times 10^{-6}\right)-\left(9.55 \times 10^{-5}\right)$ for the Banduhurang area, with the highest risk in Nandup village (uranium concentration of $27.5 \mu \mathrm{g} . \mathrm{L}^{-1}$ in January 2007) (Tab. II). The risk in the study area is within the acceptable excess individual lifetime cancer risk value of $1 \times 10^{-4}$. However, the risk in Nandup and Gohala villages is very close to the threshold value of $1 \times 10^{-4}$ and will require remediation and management of drinking water after the mining 
TABLE II

Range of excess lifetime cancer risk due to intake of uranium through drinking water.

\begin{tabular}{lcc}
\hline \multicolumn{1}{c}{ Location } & Intake $^{1}$ & Excess lifetime cancer risk $^{1}$ \\
\hline Bagjata & $5.02-24.7$ & $\left(8.81 \times 10^{-6}\right)-\left(4.34 \times 10^{-5}\right)$ \\
Banduhurang & $1.92-62.1$ & $\left(3.36 \times 10^{-6}\right)-\left(9.55 \times 10^{-5}\right)$ \\
\hline$S F_{\mathrm{o}}$ in Risk/pCi $\left(6.4 \times 10^{-11}\right) .{ }^{1}$ Daily Intake in pCi. &
\end{tabular}

TABLE III

Range of intake and hazard quotient of uranium due to ingestion of groundwater.

\begin{tabular}{lccc}
\hline Location & Intake $^{\mathbf{1}}$ & $\begin{array}{c}A D D^{\mathbf{2}} \\
\text { (average daily dose) }\end{array}$ & $\begin{array}{c}\text { HQ } \\
\text { (hazard quotient) }\end{array}$ \\
\hline Bagjata & $0.007-0.037$ & $0.00014-0.0007$ & $0.05-0.23$ \\
Banduhurang & $0.003-0.093$ & $0.00005-0.0018$ & $0.02-0.6$ \\
\hline$R f D_{\mathrm{o}}$ in $\mathrm{mg} / \mathrm{kg}$ body weight/day $\left(0.003\right.$ for uranium). ${ }^{1}$ Intake in $\mathrm{mg} /$ day. ${ }^{2} \mathrm{ADD} \mathrm{in} \mathrm{mg} / \mathrm{kg}$ body weight/day.
\end{tabular}

starts in both the proposed uranium mining areas of Bagjata and Banduhurang. The elevated levels of uranium and the associated high risk may be attributed to the uranium mineralisation of the study area.

\subsection{Daily intake estimate of uranium through drinking water and hazard quotient}

However, to know the chemical risk associated with the ingestion of uranium through water, the hazard quotient $(H Q)$ was estimated in both the study areas. The estimated exposure and hazard quotient due to intake of drinking water to the local population are given in Table III. The hazard quotients suggest that the uranium in the drinking water poses no threat to the local people. The $H Q s$ of all the locations in both the areas were below the threshold value of 1, as suggested by US-EPA. The $H Q$ ranges from 0.05 to 0.23 for the Bagjata area, while for the Banduhurang area the $H Q$ ranged from 0.02 to 0.6 . The maximum $H Q s$ were found in Gohala and Nandup villages, respectively.

\section{Conclusions}

The concentration ranges of $U(n a t)$ in the groundwater of both the study areas are within the US-EPA and WHO standards of $30 \mu \mathrm{g} . \mathrm{L}^{-1}$. The excess lifetime cancer risk due to the consumption of water in all the locations of both the study areas is within the acceptable excess individual lifetime cancer risk value of $1 \times 10^{-4}$. However, as the risk at some locations is very near to the threshold value of 1 chance in 10 000, it may stipulate remediation after mining starts. The elevated 
levels of uranium and the associated high risk may be attributed to the uranium mineralisation of the study area. The hazard quotients of all the locations in both the areas were also below the threshold value of 1, as suggested by US-EPA. The study suggests that the concentration of $U(n a t)$ in the groundwater presently does not pose any serious threat to local people but needs close investigation in the near future and stringent remedial measures should be adopted in the high risk locations.

Acknowledgement. Thanks are due to the Board of Research in Nuclear Sciences, Department of Atomic Energy, Government of India, New Delhi, for providing the funding necessary for the study. The authors are also grateful to the Health Physics Unit, Environmental Survey Laboratory, Jadugoda, and the Department of Environmental Science and Engineering, Indian School of Mines, Dhanbad, for providing the necessary laboratory facilities and other logistical support for the study.

\section{REFERENCES}

Amakom C.M., Jibiri N.N. (2010) Chemical and radiological risk assessment of uranium in borehole and well waters in the Odeda Area, Ogun State, Nigeria, Int. J. Phys. Sci. 5, 1009-1014.

Dang H.S., Jaiswal D.D., Parameswaran M., Krishnamony S. (1994) Physical Anatomical, Physiological and Metabolic Data for Reference Man-A Proposal. BARC/1994/E/043.

Dang H.S., Jaiswal D.D., Parameswaran M., Deodhar K.P., Krishnamony S. (1996) Age Dependent Physical and Anatomical Indian Data for application in Internal Dosimetry, Radiat. Prot. Dosim. 63, 217-222.

Giri S., Singh G., Jha V.N. (2011) Evaluation of radionuclides in groundwater around proposed uranium mining sites in Bagjata and Banduhurang, Jharkhand (India), Radioprotection 46, 3957.

Graham J. (1993) The legacy of one in a million in risk in perspective, Harvard Center for Risk Analysis, Risk Perspective 1, 1-2.

Guglielmotti M., Ubios A, Larumbe J, Cabrini R. (1989) Tetracycline in uranyl nitrate intoxication: its action on renal damage and $U$ retention in bone, Health Phys. 57, 403-405.

Jain S.C., Mehta S.C., Kumar B., Reddy A.R., Nagaratnam A. (1995) Formulation of the Reference Indian Adult: Anatomical and Physiological Data, Health Phys. 68, 509-522.

Keith M.S., Spoo W., Corocoran J. (1999) Toxicological profile for uranium (update). ATSDR, US Department of Health and Human Services, Atlanta, Georgia, USA.

Kelly K.E. (1991) The Myth of $10^{-6}$ as a Definition of "Acceptable Risk", Presented at the 84th Annual Meeting and Exhibition of the Air and Waste Management Association, Vancouver, BC, June 16-21.

Kolthoff I.M., Elving P.J. (1962) Treatise on Analytical Chemistry, Part II, Vol. 9.

Kurttio P., Auvinen A., Salonen L. (2002) Renal Effects of Uranium in Drinking Water, Environ. Health Perspect. 110 (4), 337-342. 
Kurttio P., Komulainen H., Leino A., Salonen L., Auvinen A., Saha H. (2005) Bone as a possible target of chemical toxicity of natural uranium in drinking water, Environ. Health Perspect. 113, 68-72.

Larivière D., Packer A.P., Mario L., Li C., Chen J., Cornett R.J. (2007) Age dependence of natural uranium and thorium concentrations in bone, Health Phys. 92, 119-126.

Leggett R.W. (1989) The behavior and chemical toxicity of uranium in the kidney: a reassessment, Health Phys. 57, 365-383.

Lohner T.W. (1997) Is $10^{-6}$ an appropriate de minimus cancer risk goal? Risk Policy Report, April 18, 31-33.

Travis C.C., Richter S.A., Crouch E.A.C., Wilson R., Klema E.D. (1987) Cancer risk management: a review of 132 federal regulatory agencies, Environ. Sci. Technol. 21, 415-420.

UNSCEAR (2000) United Nations Scientific Committee on the Effects of Atomic Radiation, Sources, Effects and Risks of Ionizing Radiation, Report to the General Assembly with Scientific Annexes, United Nations, New York. 1, 126-127.

US-EPA (1989) Health Effect Assessments Summary Tables (HEAST) and user's Guide, Office of Emergency and Remedial Response, US Environmental Protection Agency, Washington DC, USA.

US-EPA (1991) Risk Assessment Guidance for Superfund: Volume 1 Human Health Evaluation Manual (Part B, Development of Risk-based Preliminary Remediation Goals), Publication 9285.7-01B, Office of Emergency and Remedial Response, US Environmental Protection Agency, Washington DC, USA.

US-EPA (1993) Carcinogenicity assessment. IRIS (Integrated Risk Information System), 2003; US Environmental Protection Agency, Washington, DC, USA. Internet: www.epa.gov/iris

US-EPA (1994a) The Integrated Risk Information Service (IRIS) Online, Office of Environmental Health and Environmental Assessment, Environmental Criteria and Assessment Office, Cincinnati, OH. US Environmental Protection Agency, Washington, DC, USA.

US-EPA (1994b) Comparison of Health Risks Arising From the Radiological and Chemical Toxicity of Uranium, Appendix F of Radiation Site Cleanup Regulations: Technical Support Document For The Development Of Radionuclide Cleanup Levels For Soil, Review Draft, EPA 402-R-96011 A, US Environmental Protection Agency, Washington, DC, USA.

US-EPA (1999) Cancer Risk Coefficients for Environmental Exposure to Radionuclide, Federal Guidance Report No. 13, EPA-402-R-99-001, Oak Ridge National Laboratory, Oak Ridge, TN; US Environmental Protection Agency, Washington, DC, USA.

US-EPA (2003) Current Drinking Water Standards, Ground water and drinking water protection agency, pp. 1-12. US Environmental Protection Agency, Washington, DC, USA.

WHO (2004) Guidelines for Drinking-water Quality: Recommendations by World Health Organization, Edition: 3, Published by World Health Organization.

WHO (2008) Meeting the MDG drinking water and sanitation target: the urban and rural challenge of the decade. WHO Library Cataloguing-in-Publication Data. Published by World Health Organization.

WHO (2011) Guidelines for Drinking-water Quality: Chemical hazards in drinking-water - Uranium, Edition: 4, Published by World Health Organization.

Ye-shin K., Hoa-sung P., Jin-yong K., Sun-ku P., Byong-wook C., Ig-hwan S., Dong-Chun S. (2004) Health risk assessment for uranium in Korean groundwater, J. Environ. Radioact. 77, 77-85.

Zamora M.L., Tracy B.L., Zielinski J.M., Meyerhof D.P., Moss M.A. (1998) Chronic Ingestion of Uranium in Drinking Water: A Study of Kidney Bioeffects in Humans, Toxicol. Sci. 43, 31-45. 